Journal of Contemporary Educational Research

Research Article

\title{
Culture in Western Diplomacy
}

\author{
Dongling Huang \\ School of Foreign Languages, Guangdong Baiyun University, China
}

\begin{abstract}
What could be more antithetical than the alliance of the words "culture" and "political power"? Yet, for over fifty years, the process of European integration has been linking these opposing concepts. European culture, 'a sort of UFO' for most Europeans and it has become a major political and philosophical issue. Given their political and strategic importance so-called 'geo-cultural' issues have been called upon to constitute, along with geopolitical and economic issues, a governance axis. The European Union's current mode of cultural action, intrinsic to national policies, is unable to address these issues. Indeed, the EU should completely rethink its conception and political implication of culture, and recognize its great importance, both for the success of European integration, and for the new civic relationships which are developing today in local, national and global communities.
\end{abstract}

Key words: European culture; Culture; Politics; European union

Publication date: October, 2020

Publication online: 31 October, 2020

*Corresponding author: Dongling Huang, 2455458845@qq.com

\section{Introduction}

Europe, which is too often considered along market principles, is first and foremost a cultural reality. This affirmation, evident to all non-Europeans, is nevertheless difficult to conjure up at the very heart of the European Union itself (EU). It is also important to remember the fact that over the centuries the word 'culture' has been invested with multiple meanings, evolving with history and social changes to the point of encompassing everything and meaning nothing. The aim of this paper is to define what the EU presently understands as constituting culture and the place it is given in the Union's political construction. Rather than establishing a definition of culture, the objective here is to paint a picture that reflects the Union's conception of culture through its legal basis and policies, especially through its external action. If we are to consider, in parallel, the evolution of culture and that of the European Union, we realize that the former was understood as much in terms of artistic production and external practices as it was as a set of ways of thinking, sentiments, perceptions and ways of being all deeply internalized creators of identity. In recent years, considerable attention has been devoted to the impact of cultural diversity in bilateral diplomatic relations. Before being posted in a country with a different culture, diplomats have been encouraged to acquaint themselves with that culture in order to be able to converse and interact with their local counterparts and the population in general in such a manner as not to threaten sensitivities. Depending on the diplomat's own culture, this has often been difficult. At the multilateral level meaning of words and especially concepts becomes uncertain because of the multiplicity of cultures involved. This is one reason why international conventions are often accepted and even ratified by countries whose view of the subject matter vastly differs. A good example is human rights. Verbal support is given to the Universal Declaration of 1948 and the two Covenants of 1966 in every part of the world but when it comes to the interpretation of specific provisions like the one proclaiming equality between men and women, the views of various cultures vastly differ. For most of the history of humanity, the individual was seen as part of a group, the family clan, tribe or nation. This view is still held by the majority of non-Western cultures, as it was by Marxism-Leninism, a product of Western European culture. Thus, basic 
concepts mean different things in different cultures. As a result, an interpretation according to one culture also tends to criticize different interpretations according to other cultures.

\section{Historical and Jurisdiction Background}

Historically, international law and international organizations are the creation of countries belonging to the Western European culture and its American offspring. Moreover, many countries that was formerly colonized are strongly influenced by the culture of the colonizers, in particular those colonized by Britain, France and Spain. Otherwise Euro-centric views would no longer be in a position to dominate universal organizations and, in particular, the United Nations. So far, only Islamic countries have consistently upheld their own views on a number of issues. To a lesser extent, divergent views have also been presented within groups of third world countries such as the Non-Aligned Movement and the Group of 77. However, even within a given culture, strong differences can be found among individuals, groups and countries regarding specific issues. It is important that diplomats and politicians pay attention to and accept the fact of cultural diversity. If they do, they will understand the underlying causes of many conflicting attitudes and they may become more inclined to seek compromise and consensual approaches rather than attempt to impose their own culturally biased views. Currently, the catchword in international relations is globalization. This is thought to mean that the whole world should become a single unit, in which goods, persons and ideas could circulate unhindered. As the idea of globalization originates from the USA and, to a lesser extent, Western Europe, the concept is impregnated with cultural values of these regions. Thus, in the field of economic relations, private property and free markets are the core values. In political terms, democracy, transparent governance and the respect of human rights are the key concepts.

If we think of the EU emphasis on culture, from a historical and legal point of view, we will notice that its political 'taking into account' and its institutionalization within the EU, started only in 1993, when the Treaty on European Union 2 entered into force, aimed at 'encouraging', 'supporting' and 'supplementing' the actions of the Member States, "while respecting their national and regional diversity and at the same time bringing the common cultural heritage to the fore", the article 151 (which is now 167 in the Lisbon
Treaty) gave some competence to the EU, but only in a 'complementary' form which meant that any act of harmonization of legal and regulatory provisions of the Member States was excluded from the scope of the article. This provision is still valid today.

More recently, social tensions that have become stronger not only on the international but also on the national, regional and local scale, particularly in urban settings, high- light further the need for tolerance not only between societies, but within them as well, raising a new not only question regarding the role of culture, but also the link between culture and democracy and criteria inherent to these societies' identity and selfperception. In light of these considerations, both historical and geo- political, this study will aim to address this new identity- orientated understanding of culture. Little by little culture has acquired identity that has been growing stronger and stronger to the point of identity being assimilated into culture. Apart from being extremely reduction such a 'definition' could end up being "anti-cultural "ridding Europe of its long tradition of integration and diversity, in the name of safeguarding particularities. The confrontation of cultural dimensions of our societies and has given rise to numerous questions: is identity a factor that explains integration in other political domains, as it is currently the case? Will it be in the future, the driving factor in the creation of a common cultural policy within the EU or an additional obstacle? As the Euro barometer (Flash 257) shows, citizens considered freedom and democratic values as the most essential factor at the EU and the personal level. The third most important issue was immigration and this was followed by cultural and religious issues that citizens would like to be taken into consideration. The identity issue is present at every stage of society: at the personal stage but also at the community level. To understand its complex interaction, we will refer to the work of Micheline Rey in order to distinguish three points of view:

(1) First point of view: The one of an individual identity represents the coherence of his action modes.

(2) Second, the social actor point of view: Cultural identity has become a kind of legitimating or claiming strategy most often seen in cases of conflict when economic or political agendas as imbued with the noble "cultural identity" rendering the resolution of such conflicts particularly complex.

(3) Third, in the researcher's mind, cultural identity would be a kind of heuristic hypothesis, a conceptual 
tool that we can use as a regulating principle to grasp our reflection about the world.

In the work of Durkheim, Parsons, Bakhtin and Bourdieu, culture comes to occupy a privileged position, its structure and forms linked to specific social and historical contexts yet partly autonomous of social structure, institutions and social interaction. But Durkhiem, Parsons, and the Frank- Furt School also theorize culture partly in terms of its role in securing social integration, while simultaneous arguing that culture always involves immanent, transcendent universal values. Then, according to Swingewood, the modern concept of culture arose simultaneously with the idea of modernity and the development of industrial capitalism, laid the basis for the autonomisation of culture into distinctive spheres or fields, institutions and practices each structured in terms of specific internal logic and properties. In 2009, identity surrounded one more time in the political debate with a public vote regarding minarets in Switzerland. And then, President Sarkozy had sought to use a national identity debate in France to heal social rifts: Should France implement 'integration contracts' which would set minimal levels of language and cultural knowledge for citizenship? And should students be required to sing the national anthem 'La Marseillaise' at least once a year? Some fear that these types of questions even the debates themselves invite assumptions that generations of immigrants have already undermined France's identity and may provoke nationalist sentiments long championed by Le Pen. "When you put immigration and national identity side by side, it creates the notion that immigration poses a threat to national identity which can inspire racism". Paradoxically, the extreme right French leader's finding was quite similar: "This country is suffering a major crisis of identity that is driving it into chaos," Marine Le Pen said. "What is French and Frenchness?" Instead of this fruitless question, it would have been much more useful and clever to launch a debate on "What is European or Europeanist?". This three months debate, confining citizens to a reductive and discriminatory perspective, moved them away from any European consciousness, and made religion, roots, education and "cultural belonging" the heart of immigration matter, in a negative way. France is home to Europe's largest Muslim minority and Islam now ranks as the nation's second religion, so opinion was rattled by the Swiss referendum vote to ban minaret construction. European culture is nourished by the diversity of national and regional cultures, languages and identities including those of the minorities. Culture and Foreign affairs since 1975, the European community has developed various relations with third countries through accords of association, cooperation, or partnership whose content has evolved while political dialogue has been added to the economic dimension conditioning it at times. Audiovisual material can be examined as a perfect example to analyze the continuous battle that has opposed the EU and the USA for decades, first within the GATT and currently in the framework of WTO, focusing on the potential consequences of this new cultural challenge, starting from those which concern the very identity of Europe. Has the defense of this "European cultural identity" not become a banner that is brandished in order to conceal purely economic and political interests that are the real motivation behind EU? Along the same lines, in the field of European integration, culture, deprived of a real recognition, is of utmost importance. The latest enlargements of the EU in 2004 and in 2007, led us to conclude that most of the obstacles that oppose EU enlargement to include certain countries derive from an identityorientated interpretation of culture. When the European Commission asked about the negative consequences of the integration of central and Eastern European countries (CEE) in the EU, $54 \%$ of the EU respondents consider that enlargement has caused "problems because of the divergent cultural traditions" of the new Member States. "In only three EU countries did a clear majority disagree that the expansions brought up issues related to an increased cultural diversity across Member States. In most countries, usually slim majority agreed that the inclusion of the CEE countries in the European Union created problems because of the existence of "too different cultures and values among the different countries of the European Union". This opinion was more frequently confirmed in the EU15 region with $57 \%$, and more especially in Germany (65\%), Austria (64\%), Greece (63\%), Italy (62\%) and Portugal and Cyprus (both 61\%).

Reluctances and disagreements that arise from the moment one 'touches culture' are based on a set of factors, often rooted in incomprehension, ignorance or simply semantic confusion. In this regard the endless debate about Turkey and the non-ratification of the Constitution provide two different very interesting parallels. All of those examples demonstrate the need to establish an identifiable European culture that could 
be used as a reference in the eventual case of future European integration. On the international arena, the same finding of failure could be established. The case of Kosovo, that has become a major issue in Europe for a while, could be taken as another example in order to demonstrate to what extent the search for a political solution is often contradictory to a cultural and ethnic heritage. "Inevitably this leads to a new analysis of the role of culture in the generation of conflicts, as well as in their resolution. As examples, Ferdinand Richard also reminds us the responsibility of popular musicians launching songs of war and hate on the waves of Radio des Mille Collines in Rwanda, or through turbo-folk songs in former Yugoslavia. He also incites us to read the "European cultural activists Ritva Mitchell and Simon Mundy's reports on Vukovar in 1997 for the Council of Europe. In Vukovar, at a time when guns were still hot, they were sent in UN helicopters in the middle of the city as the first attempt to restart dialogue between opposed communities, directly on the ceasefire line. Somewhere in the system, someone finally came to the clever conclusion that only cultural activists could re-initiate the knitting of the threads of peace". Ten years later, the identity problem brought to our attention by the declaration of independence of Kosovo in 2008 illustrates how despite of Europe's excessive references to culture, the international community's discussion of culture, its role and cultural exchanges, is at its initial stage, while it could contribute to a better EU international recognition. Unable to speak with one voice in such important issues as Iraq war, eighteen years ago, or as Libya, soft power was and seems to be still the only way for the EU to get international recognition as a global actor. In 2004, some authors like Mark Leonard19, T.R. Reid and Jeremy Rifkin even published books contending that, despite limited military resources, much of European soft power derives from its hard economic power.

\section{Conclusion}

To conclude, the main characteristic of the EU's cultural policy seems to be its very inexistence. This appears particularly paradoxical given that culture has become an integral component of other EU policies to the point of becoming crucial in various sectors, some as surprising as the Common foreign and security policy (CFSP). Its 'dilution' in other policies, although prudent, proves its usefulness in fields such as immigration and European integration, sustainable development on local and national scales, cooperation and valorization, to name just a few. Following Jürgen Habermas33, who judged that principles of democracy should be reformulated in the light of changes that have taken place in society, the same diagnosis should be applied to culture. The relations between an individual, the social and the political level are shifting constantly. The tendency that is slowly taking us towards the creation of a political, rather than purely economic European Union further highlights its importance. Policies, that are not linked to the social sphere, that underpins them as well as it nourishes culture, are deprived of sense and finality. The European culture, if it should be possible to define it and recognize it one day, should be framed by policies in its image, revealing its essence that is "kaleidoscopic culture". All attempts at a common cultural policy, in as much as it is possible, must be aware of this specificity. The future, let us hope, will confirm this, unless the questions and fears that make and unmake Europe, writing its history despite of themselves, shall decide differently.

\section{References}

[1] Bruce C. Berets and Baguettes? France Rethinks Its Identity, Time Magazine, November 04, 2009 and Why France's National Identity Debate Backfired, Time Magazine, February 12,2010

[2] Casey, Terence, Europe, Soft Power, and Genteel Stagnation[M], Comparative European Politics review vol 4.

[3] Ferdinand Richard's speech, "The role of Culture in Defense and Security Policy: Soft power and political ecology", European Green Party, Budapest, April 2nd, 2011.

[4] Hilary Clinton, Confirmation hearings discourse of jan 13.

[5] Interview from Marine Le Pen, Europe 1 radio station, on October 28, 2009 and quoted by Time Magazine. Mainly with the Mediterranean and African-Caribbean-Pacific (ACP) countries through Conventions of Lomé: I, II, III, IV (19751989).

[6] Jan mellisen,Cynthia, Culture communicates:US diplomacy the works[M]

[7] Swingwood Alan, Cultural theory and problem of modernity, (1998). 